\title{
Tables
}

\section{Text Tables}

1 Population of the Central Coasts in the Eighteenth Century

2 Militia Units along the Gulf Coast prior to the Bourbon Military Reforms, 1763-66

3 Militia Units in the Jurisdiction of Veracruz prior to the Bourbon Military Reforms, 1758

4 Militia Units of New Galicia prior to the Bourbon Military Reforms, 1753-72

5 Militia Units in the Archdiocese of Puebla prior to the Bourbon Military Reforms, 1758

6 Militia Units in Tuxtla prior to the Bourbon Military Reforms, 1775

7 Provincial Militiamen in Tuxtla after the Bourbon Military Reforms of 1775

8 Provincial Militiamen in Guachinango after the Bourbon Military Reforms of 1781

9 Militia Units in Guachinango prior to the Bourbon Military Reforms, 1781

10 Militia Strength of Selected Gulf Coast Sites before and after the Bourbon Military Reforms

11 Average Number of Years Spent by Free-Colored Officers in the Militia, 1766-84

12 Military Performance Reviews for Free-Colored Officers in Mexico City, Veracruz, Tuxtla, Tehuantepec, New Galicia, and Michoacán, 1766-84

13 Average Age of Free-Colored Officers by Rank, 1768-72

14 Geographical Place of Origin for Free-Colored Officers in New Spain 
15 Monthly Salary of Free-Colored Militiamen and the Veteran Cadre, 1777

16 Monthly Distribution of Provincial Militiamen in the Pardo Companies of Mexico City and Puebla, 1768-75

17 Racial Breakdown of the Militiamen in Puebla's Cuerpo de Pardos y Morenos, 1792

18 Monthly Distribution of Provincial Militiamen in the Pardo Company of Jalapa, 1774

19 Occupational Structure of the Free-Colored Militiamen in Mexico City, 1767

20 Occupational Structure of Free-Colored Men in Mexico City, 1753

21 Occupational Structure of the Free-Colored Militiamen in Puebla, 1710

22 Occupational Structure of the Free-Colored Militiamen in Puebla, 1792

23 Occupational Structure of the Free-Colored Men in Puebla, 1720

24 Occupational Structure of the Free-Colored Men in Puebla, Tribute Census of 1794

25 Occupational Structure of the Free-Colored Men in Puebla, Parish Census of 1790-92

26 Occupational Structure of the Free-Colored Militiamen in Orizaba, 1769

27 Occupational Structure of the Free-Colored Militiamen in Patzcuaro, 1762

28 Occupational Structure of the Free-Colored Militiamen in Valladolid, 1762

29 Occupational Structure of the Free-Colored Men in Igualapa, 1791

30 Occupational Structure of the Free-Colored Militiamen in Igualapa, 1791

31 Occupational Structure of the Free-Colored Militiamen in Acayucan, 1793-94

32 Occupational Structure of the Free-Colored Militiamen in Tampico, 1780

33 Marriage Structure of Free-Colored Militiamen and Civilians in Puebla, 1720-92

34 Marriage Structure of Igualapa, 1791

35 Tribute Revenues Submitted to the Caja de Mexico during the Sixteenth and Seventeenth Centuries

36 Racial References to Free-Colored Militia in Civil Documents, 1703-41 
Appendix Tables

A.1 List of Recruits by Race for the Provincial Regiment of

Tampico, Panuco, and the Jurisdiction of Huexutla, 1766

A.2 Racial Classification of Officer Corps in the Provinces of

Tampico, Panuco, and the Jurisdiction of Huextla, 1766

A.3 Provincial Militia Units in New Spain, 1766

A.4 Provincial Militia Units in New Spain, 1784

A.5 The Militia Forces According to the Crespo Plan 233

A.6 Militia Units of the Costa Sur, Extending from the Jurisdiction of Acaponeta to Tehuantepec, Proposed Changes in 1793

A.7 Militia Units in Nuevo Santander, Proposed Changes in 1793

A.8 Militia Units in Tabasco, Proposed Changes in 1793

A.9 Militia Units of the Seno Mexicano Extending from Tampico and Panuco to the River of Guazacualco, Proposed Changes in $1793 \quad 235$

A.1o Militia Units in the Yucatan, 1778

A.11 The Credit Network of Joseph Escobar the Elder 236

A.12 Average Age of the Free-Colored Officers by Rank, 1768-72 237 


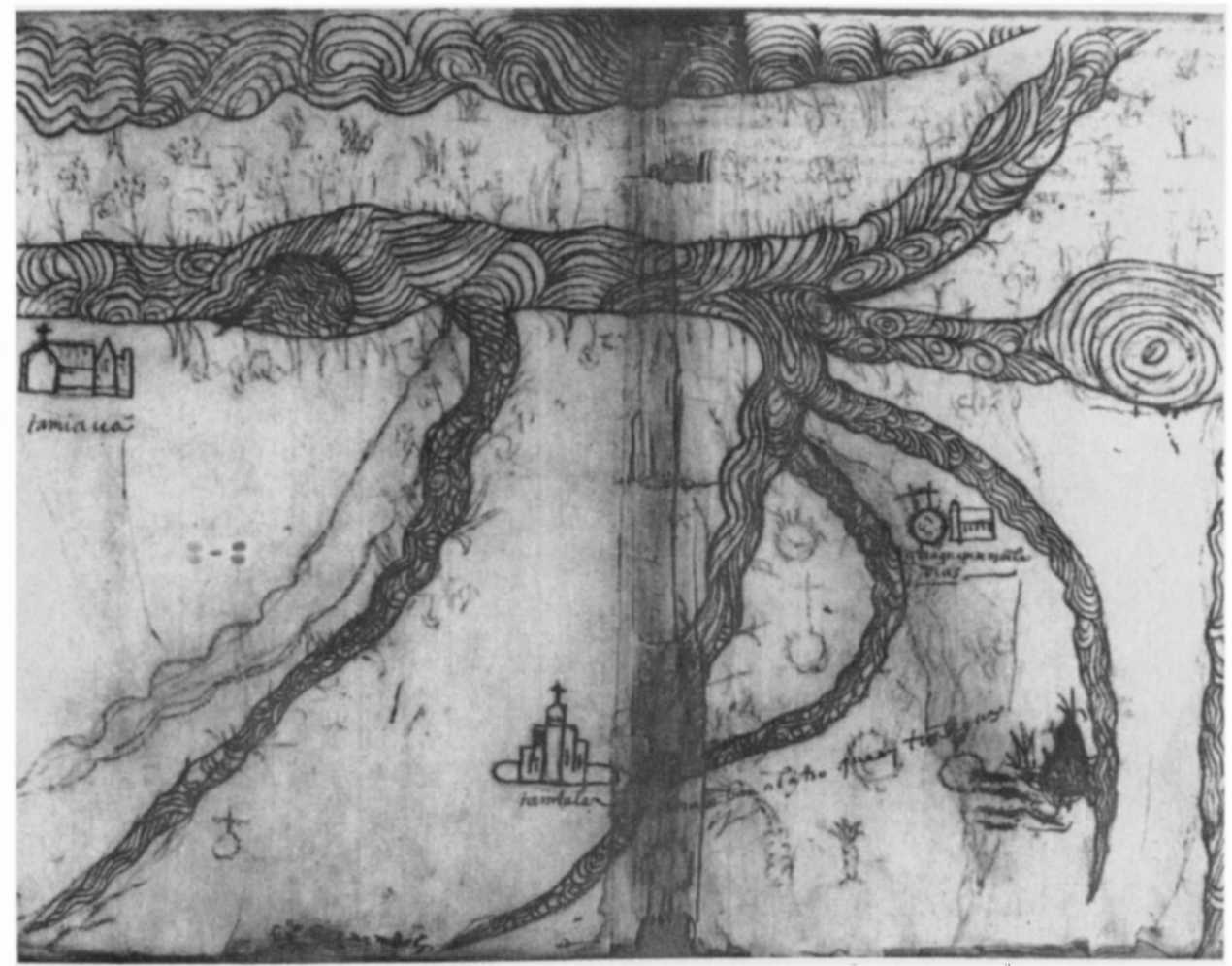

The region of Tamiagua, late sixteenth century, 1583. (Mapa Tamiagua y Tamtolon, signadario Cristobal ... de Arellano, alcalde mayor, 1583. Archivo General de la Nación, Tierras, vol. 277 , exp. 13, fol. 8. Original dimensions $32 \times 41 \mathrm{~cm}$.)

Overleaf: The Cabecera of Acayucan and its environs, 1781. (Mapa provincial de Acayucan, Veracruz, 1781. Archivo General de la Nación, Tierras, vol. 3601, exp. 7, fol. 5. Original dimensions $31 \times 43 \mathrm{~cm}$.) 


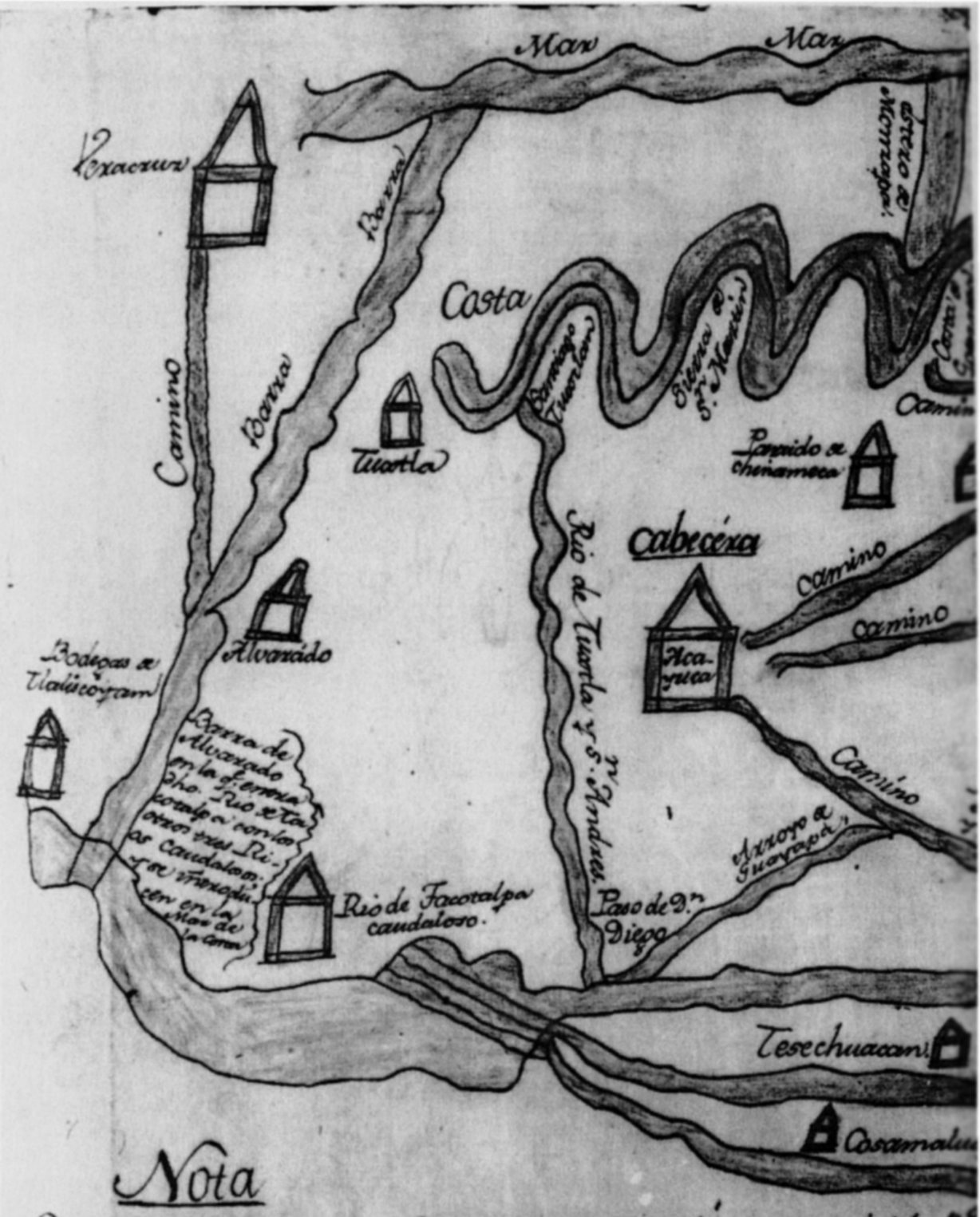

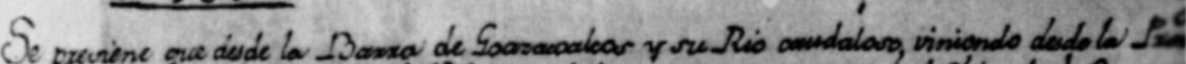

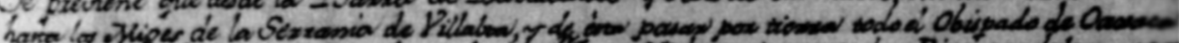

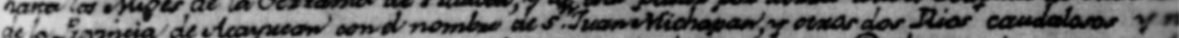

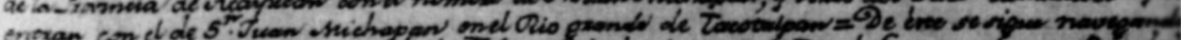

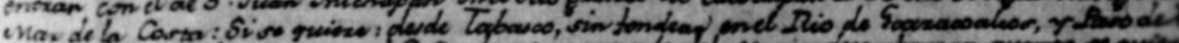

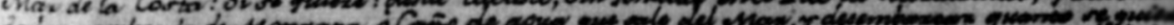

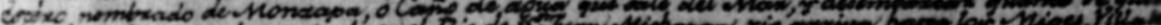

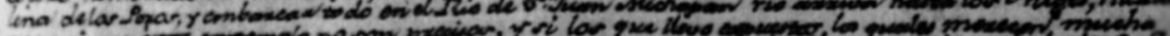

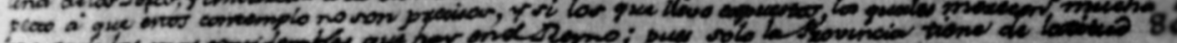

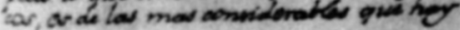




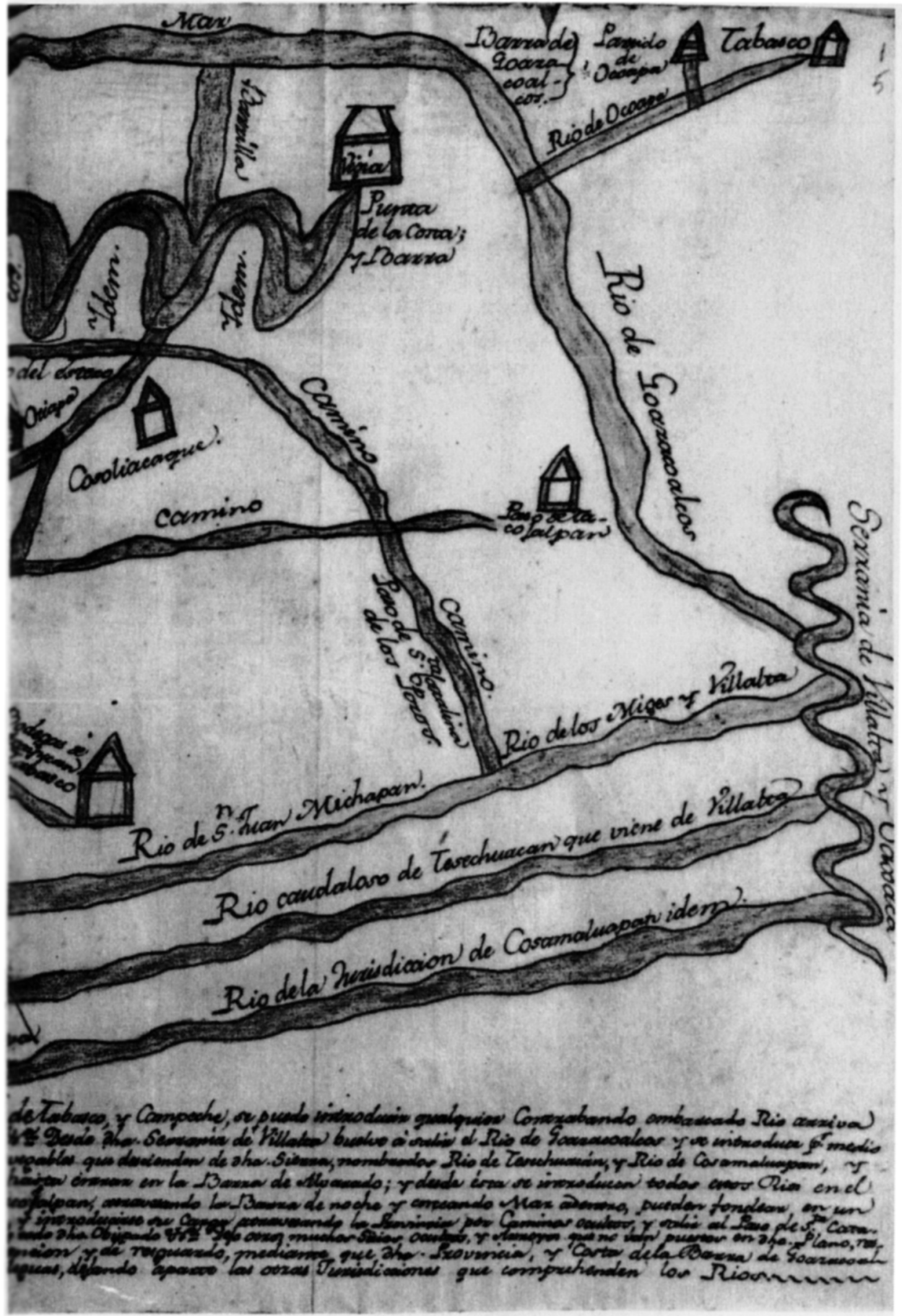




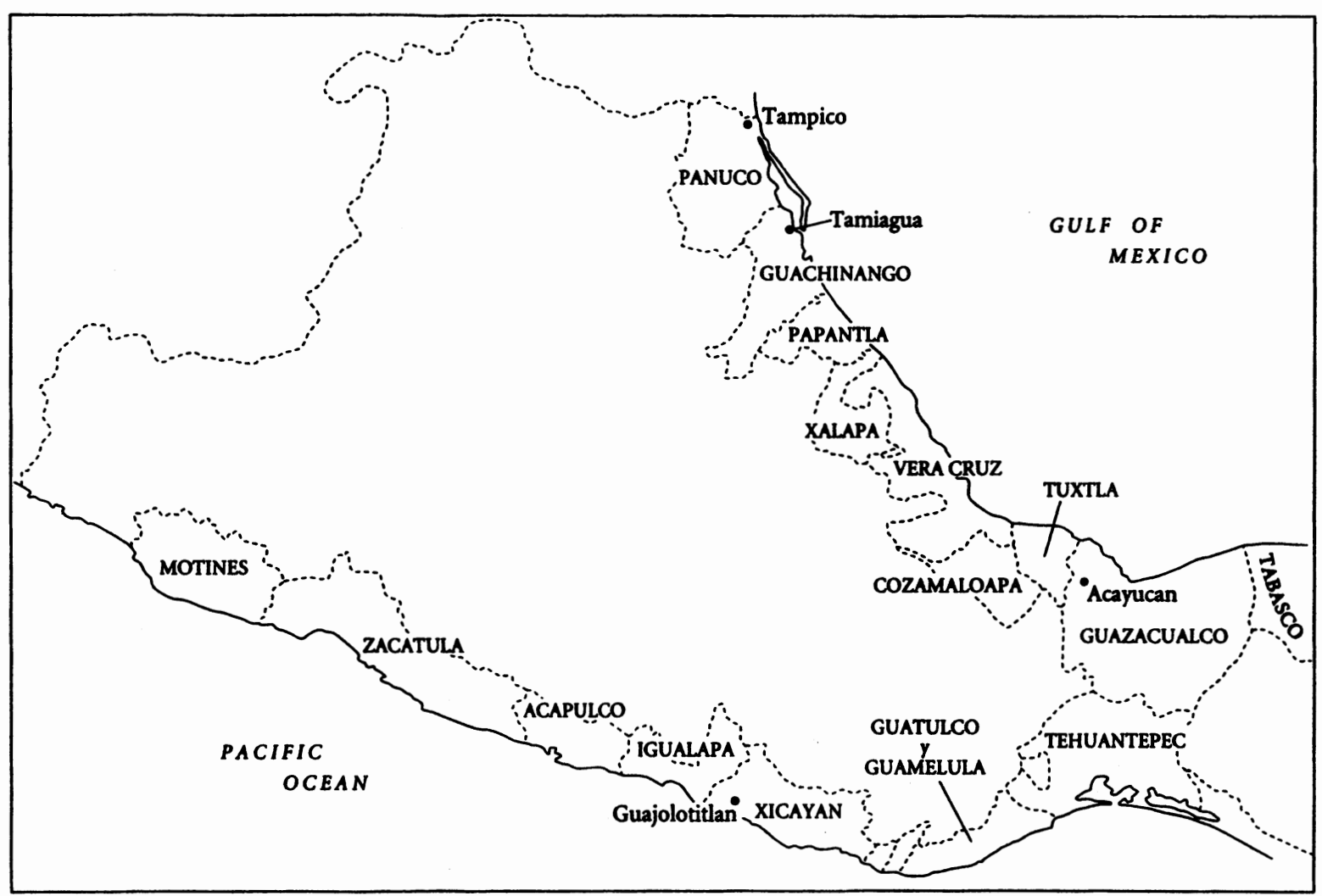

The coastal provinces of New Spain, eighteenth century. (Information from Peter Gerhard, Geografia Historica de la Nueva España, 1519-1821 [Mexico City: Universidad Autónoma de México, 1986.) 